KAMPURUI JURNAL KESEHATAN MASYARAKAT

https://www.ejournal.lppmunidayan.ac.id/index. php/kesmas

e-ISSN: 2549-6654

P-ISSN: 2338-610x

Keywords: Covid 19, Ibu hamil, Kesehatan mental

Kata kunci: Covid 19, Pregnant Women, Mental Health

Korespondensi Penulis:

Sartika.suyuti@umi.ac.id

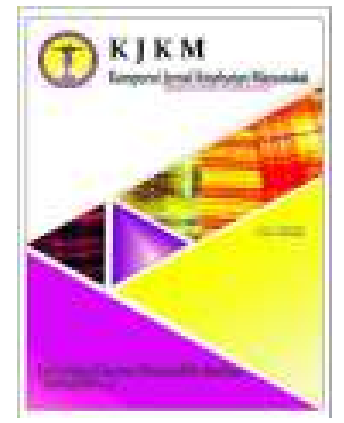

PENERBIT

Fakultas Kesehatan Masyarakat Universitas Dayanu Ikhsanuddin

Alamat: Jl. Sultan Dayanu Ikhsanuddin No. 124, Baubau 93724

\section{Gambaran Kesehatan Mental Ibu Hamil di Puskesmas Pangkajene}

\author{
Sartika1), Nurul Hikmah'), Andi Sani 1) \\ 1) Kesehatan Masyarakat, Universitas Muslim \\ Indonesia Makassar, Indonesia
}

Dikirim: 14 Desember 2021

Direvisi: 20 Desember 2021

Disetujui: 27 Desember 2021

\section{ABSTRACT}

The COVID-19 pandemic has not only caused a public health crisis but also social, demographic and economic as well as psychosocial effects. Anxiety caused during pregnancy has a negative impact on pregnancy, such as increasing the risk of preeclampsia, depression, nausea, vomiting and even causing premature labor or negative miscarriage, including pregnant women. The purpose of this study was to determine the mental health picture of pregnant women during the covid 19 pandemic. This study is a quantitative study with a descriptive approach. The population is pregnant women who come to visit for antenatal care activities. The number of samples in this study was 117 pregnant women obtained using the Lameshow formula. the source of data is primary data from interviews using questionnaires while secondary data from $\mathrm{MCH}$ data at puskesmas, health offices and related journals. The results of this study found that the description of mental health disorders that occurred in Pangkajene Health Center was 35 people suffering from depression (29.9\%), anxiety as many as 52 (44.4\%) and stress as many as 21 people (17.1\%). It is expected that the officers at the community health service center, namely midwives, doctors and nurses, will not only carry out physical examinations but also provide counseling services for pregnant women who have mental health disorders.

INTISARI

Pandemi COVID-19 tidak hanya menyebabkan krisis kesehatan pada 
masyarakat tetapi juga sosial, demografis dan ekonomi serta efek psikososial. Kecemasan yang ditimbulkan saat hamil berdampak negatif pada kehamilan, seperti meningkatkan risiko preeklamsia, depresi, mual, muntah bahkan menyebabkan persalinan prematur atau keguguran negatif termasuk wanita hamil. Tujuan penelitian ini untuk mengetahui gambaran kesehatan mental ibu hamil di masa pandemi covid 19. penelitian ini merupakan penelitian kuantitatif dengan pendekatan deskriftif. Poulasinya adalah ibu hamil yang datang berkunjung untuk kegiatan antenala care. Jumlah sampel dalam penelitian ini sbenayak 117 ibu hamil yang diperoleh menggunakan rumus lameshow. sumber data berupa data primer dari hasil wawancara menggunakan kuesioner sedangkan data sekunder dari data KIA di puskesmas, dinas kesehatan dan jurnal terkait. Hasil penelitian ini menemukan bahwa Gambaran gangguan kesehatan mental yang terjadi di Puskesmas Pangkajene yakni sebanyak 35 orang menderita depresi (29.9\%), kecemasan sebanyak 52 (44.4\%) dan stress sebanyak 21 orang (17.1\%). Diharapkan pada petugas di pusat pelayanana kesehatan masyarakat yakni bidan, dokter maupun perawat tidak hanya melakukan pemeriksaan fisik saja tapi juga membuka layanan konseling untuk ibu hamil yang memiliki gangguan kesehatan mental.

\section{PENDAHULUAN}

Pandemi covid 19 belum menunjukkan tanda-tanda penurunan kasus di Indonesia sehingga masih ada aturan terkait kontak social serta ketidakstabilan kehidupan ekonomi. Ketidakpastian dari Pandemi COVID-19 membuat orang rentan terhadap kecemasan parah. Penelitian telah membuktikan bahwa Ibu hamil sangat rentan terhadap kecemasan dengan prevalensi kecemasan kehamilan antara 15\% dan 23\% sebagai perbandingan dengan 3 sampai 5\% gejala kecemasan pada populasi umum (Nath S, Ryan EG, Trevillion K, 2018). Di seluruh dunia, sekitar 10\% wanita hamil dan 13\% wanita yang baru saja melahirkan mengalami gangguan mental, terutama depresi. Di negara berkembang bahkan lebih tinggi, yaitu 15,6\% selama kehamilan dan 19,8\% setelah melahirkan. Dalam kasus yang parah, ibu hamil dapat melakukan bunuh diri. Selain itu, ibu yang mengalami gangguan kesehatan mental tidak dapat melakukan peran dengan baik (WHO, 2020) Selain itu, Ibu hamil tercatat sebagai salah satu kelompok rentan risiko terinfeksi COVID-19 dikarenakan pada masa kehamilan terjadinya perubahan fisiologi yang mengakibatkan penurunan kekebalan parsial (Liang, H., \& Acharya, 2020) dan dapat menyebabkan dampak yang serius bagi ibu hamil.

Informasi tentang COVID-19 hingga saat ini masih sangat terbatas termasuk data ibu hamil yang terkonfirmasi positif COVID-19 belum dapat disimpulkan di Indonesia (Afritayeni et al., 2018).Hasil penelitian dari 55 wanita hamil dan 46 neonatus yang terinfeksi COVID-19 tidak dapat dipastikan adanya penularan vertikal dan belum diketahui apakah meningkatkatkan kasus keguguran dan kelahiran mati (Rezaee \& Framarzi, 2014). Berdasarkan data saat ini, Covid 19 tidak menyebabkan infeksi yang parah pada wanita hamil karena mereka biasanya masih muda dan tanpa penyakit penyerta Namun, pandemi COVID-19 tidak hanya menyebabkan krisis kesehatan pada masyarakat tetapi juga sosial, demografis dan ekonomi serta efek psikososial negatif termasuk wanita hamil.

Kecemasan yang ditimbulkan saat hamil berdampak negatif pada kehamilan, seperti meningkatkan risiko preeklamsia, depresi, mual, muntah bahkan menyebabkan persalinan prematur atau keguguran (Sasaki T-K, Yoshida A, 2013). Kecemasan ibu hamil juga dapat menyebabkan efek buruk pada bayi baru lahir, seperti berat badan lahir rendah, hambatan pertumbuhan atau skor APGAR rendah (Abazarnejad T, Ahmadi A, Nouhi E, 2019).

Pada survey awal dilakukan wawancara singkat terhadap Bidan dan perawat di Bidang KIA (Kesehatan Ibu dan Anak) serta ibu hamil yang datang untuk kunjungan kehamilan di Puskesmas Pangkajene dengan jumlah 8 orang. Informasi yang didapatkan 
dari bidan Puskesmas bahwa Persentase kunjungan ANC Menurun drastis di masa Pandemi Covid 19, yang sebelumnya rata-rata kunjungan bulanan sebanyak 200-300 orang, sekarang hanya di rentang 100 kunjungan. Sedangkan dari Ibu hamil sendiri didapatkan informasi bahwa mereka sebenarnya takut dan cemas untuk ke Puskemas dan khawatir dengan kondisi kehamilan mereka selama pandemi covid 19. Hasil pengukuran kuesioner HARS pada 8 ibu hamil adalah 6 orang mengalami kecemasan yakni 2 kecemasan berat, 3 kecemasan sedang dan 1 orang kecemasan ringan. Informasi tambahan yang didapatkan, sekitar 75 persen dari ibu hamil tersebut tidak mengetahui protokol pencegahan COVID-19.

Penelitian ini merupakan penelitian kuantitatif dengan pendekatan deskriptif. Adapun tujuan penelitian untuk menggambarkan kesehatan mental ibu hamil selama masa pandemi Covid 19 di Puskesmas Pangkajene.

\section{METODE PENELITIAN}

Jenis penelitian yang digunakan adalah penelitian kuantitatif dengan pendekatan deskriptif untuk memberikan gambaran kesehatan mental ibu hamil di lokasi penelitian yakni Puskesmas Pangkajene Kabupaten Sidenreng Rappang Provinsi Sulawesi Selatan yang dimulai dari januari 2021 sampai Maret 2021. Variabel dalam penelitian ini adalah karakteristik demografik responden yang terdiri dari umur, tingkat pendidikan dan jenis pekerjaan responden serta kesehatan mental responden yang terdiri dari gangguan stress, kecemasan, dan depresi. Variabel kesehatan mental diukur menggunakan kuesioner DASS (Depression, Anxiety, Stress Scale) yang terdiri dari 42 item pernyataan dengan rentang skor jawaban 0-3. Selain untuk mengidentifikasi kondisi kesehatan mental, Kuesioner DASS juga bisa mengidentifikasi tingkatan kesehatan mental ibu hamil yang terdiri dari tingkatan ringan, sedang, parah dan sangat parah. Populasi dalam penelitian iniadalah semua ibu hamil yang melakukan kunjungan kehamilan selama periode pengumpulan data.
Perhitungan jumlah sampel minimal size (sampel minimal penelitian) menggunakan rumus Lameshow sehingga dihasilkan jumlah sampel sebesar 117 responden.

$$
n=\frac{4 \cdot p \cdot q}{d^{2}}
$$

Keterangan:

$\mathrm{n}$ = besar sampel

$\mathrm{p}$ =proporsi kejadian gangguan kesehatan mental pada ibu hamil yaitu 0,09\% (tahun 2020)

$\mathrm{q}=1-\mathrm{p}$ (proporsi ibu hamil yang tidak mengalami gangguan kesehatan mental)

$\mathrm{d}=$ limit dari error $0,05 \%$ atau $5 \%$

$$
\begin{aligned}
& n=\frac{4 \cdot 0, .0,09 \cdot 0,81}{0,05^{2}} \\
& n=\frac{0,2916}{0,0025}
\end{aligned}
$$

$$
n=116,64=117 \text { responden }
$$

Teknik pengambilan sampel yang digunakan adalah metode Accidental sampling yaitu suatu metode penentuan sampel dengan mengambil responden yang kebetulan ada atau tersedia di suatu tempat sesuai dengan konteks penelitian (Notoatmodjo, 2010). Dalam hal ini, sampel merupakan ibu hamil yang datang di puskesmas Pangkajene pada saat peneliti melakukan pengumpulan data. Metode pengumpulan data dilakukan dengan melakukan observasi dan wawancara responden menggunakan kuesioner. Sumber data dalam penelitian ini terdiri dari data primer dan data sekunder. Data primer berasal dari data yang didapatkan langsung melalui wawancara dengan responden sedangkan data sekunder berupa data jumlah kunjungan ibu hamil di puskesmas serta data jumlah kasus kesehatan mental ibu hamil melalui berbagai buku dan jurnal penelitian terkait. Data hasil penelitian yang telah dikumpulkan kemudian dimasukkan ke dalam aplikasi pengolah data setelah itu ditabulasi kemudian diolah menggunakan komputer program SPSS. Data kuantitatif tersebut selanjutnya diolah secara univariat untuk melihat distribusi frekuensi variabel penelitian 


\section{HASIL}

Penelitian dilaksanakan di Puskesmas Pangkajene pada bulan Januari-Maret 2021. Jumlah responden yang berhasil dikumpulkan dalam penelitian ini sebanyak 117 ibu hamil yang melakukan kunjungan kehamilan di Puskesmas Pangkajene. Hasil Penelitian sebagai berikut : karakteristik umum sampel menurut umur responden pada penelitian ini dibagi dalam tiga kelompok umur yakni kelompok umur $<20$ tahun, 20-35 tahun, >35 tahun, tabel tersebut menunjukkan bahwa responden yang berumur 20-35 tahun paling banyak dibandingkan kelompok umur yang lain yakni sebesar 47,9\%, sedangkan kelompok umur $<20$ tahun paling sedikit yakni sebesar 23,9\%. Karakteristik sampel menurut tingkat pendidikan sampel pada penelitian ini dibagi dalam 6 tingkatan yaitu tidak pernah sekolah, tidak tamat SD, tamat SD, tamat SMP, tamat SMA dan tamat Akademi/PT.Umumnya responden penelitian ini tamat SMA sebanyak 41 orang $(41,9 \%)$ dan yang paling sedikit adalah yang tamat SMP sebanyak 11 orang $(11,1 \%)$ Karakteristik sampel menurut jenis pekerjaan yang paling banyak adalah yang tidak bekerja atau sebagai ibu rumah tangga sebesar 57 orang $(48,7 \%)$, yang paling sedikit sebagai petani yakni 4 orang $(3,4 \%)$.

\begin{tabular}{l}
\multicolumn{3}{l}{$\begin{array}{c}\text { Tabel } 1 \text { Karakteristik Umur } \\
\text { Ibu Hamil di Puskesmas Pangkajene }\end{array}$} \\
\begin{tabular}{lll}
\hline Karakteristik Umum & n & \% \\
\hline Umur & & \\
$<20$ tahun & 6 & 23.9 \\
20-35 tahun & 99 & 47.9 \\
$>35$ tahun & 12 & 28.2 \\
\hline Pendidikan Terakhir & \\
Tamat SD & 14 & 12,0 \\
Tamat SMP & 13 & 11,1 \\
Tamat SMA & 49 & 41,9 \\
Tamat akademi/ PT & 41 & 35,0 \\
\hline Total & 117 & 100 \\
\hline
\end{tabular}
\end{tabular}

Sumber : Data Primer, 2021
Tabel 2 Karakteristik Jenis pekerjaan Ibu Hamil di Puskesmas Pangkajene

\begin{tabular}{lcc}
\hline Karakteristik Umum & n & \% \\
\hline Jenis pekerjaan & 11 & 9,4 \\
PNS & 4 & 3,4 \\
Petani & 33 & 28,2 \\
Wiraswasta & 12 & 10,3 \\
Lain-lain & 57 & 48,7 \\
Tidak bekerja & $\mathbf{1 1 7}$ & $\mathbf{1 0 0}$ \\
\hline Total
\end{tabular}

Sumber : Data Primer, 2021

Tabel 3 menunujukkan bahwa gangguan kesehatan mental pada ibu hamil yang ditemukan dalam penelitian ini adalah sebanyak 35 ibu hamil mengalami depresi $(29,9 \%)$, yang mengalami kecemasan sebesar 52 orang $(44,4 \%)$, dan yang mengalami stress sebanyak 21 orang $(17,1 \%)$.

Tabel 3 Gangguan Kesehatan Mental pada Ibu Hamil di Puskesmas Pangkajene

\begin{tabular}{ccccc}
$\begin{array}{c}\text { Gangguan } \\
\text { Kesehatan } \\
\text { Mental }\end{array}$ & \multicolumn{2}{l}{ Ya } & \multicolumn{2}{l}{ Tidak } \\
\hline & $\mathrm{n}$ & $\%$ & $\mathrm{n}$ & $\%$ \\
\hline Depresi & 35 & 29,9 & 82 & 70,1 \\
\hline Kecemasan & 52 & 44,4 & 65 & 55,6 \\
\hline Stres & 21 & 17,1 & 91 & 82,9 \\
\hline
\end{tabular}

Sumber: Data Primer, 2021

Tabel 4 menunjukkan gangguan kesehatan mental berupa depresi lebih banyak diderita pada tingkatan depresi sedang yakni 15 orang $(12,8 \%)$ dan paling sedikit diderita pada depresi sangat parah yakni 2 orang $(1,7 \%)$. Gangguan mental berupa kecemasan lebih banyak diderita pada tingkatan ringan yakni 20 orang $(17,1 \%)$ dan paling sedikit pada tingkatan sangat parah dan parah yakni 9 orang $(7,7 \%)$. Sedangkan pada gangguan mental berupa stress, umumnya lebih banyak diderita ibu hamil pada tingkatan stress sedang dan tidak ada responden yang mengalami stress yang sangat parah. 
Tabel 4 Gangguan Kesehatan Mental pada Ibu Hamil di Puskesmas Pangkajene

\begin{tabular}{|c|c|c|c|}
\hline $\begin{array}{c}\text { Gangguan } \\
\text { Kesehatan } \\
\text { Mental }\end{array}$ & Tingkatan & $\mathrm{N}$ & $\%$ \\
\hline \multirow{5}{*}{ Depresi } & $\begin{array}{l}\text { Sangat } \\
\text { Parah }\end{array}$ & 2 & 1,7 \\
\hline & Parah & 6 & 5,1 \\
\hline & Sedang & 15 & 12,8 \\
\hline & Ringan & 12 & 10,3 \\
\hline & Normal & 82 & 70,1 \\
\hline \multirow{5}{*}{ Kecemasan } & $\begin{array}{l}\text { Sangat } \\
\text { Parah }\end{array}$ & 9 & 7,7 \\
\hline & Parah & 9 & 7,7 \\
\hline & Sedang & 14 & 12,0 \\
\hline & Ringan & 20 & 17,1 \\
\hline & Normal & 65 & 55,6 \\
\hline \multirow{5}{*}{ Stres } & $\begin{array}{l}\text { Sangat } \\
\text { Parah }\end{array}$ & 0 & 0,0 \\
\hline & Parah & 2 & 1,7 \\
\hline & Sedang & 10 & 8,5 \\
\hline & Ringan & 9 & 7,7 \\
\hline & Normal & 96 & 82,1 \\
\hline Jumlah & 117 & & 0,0 \\
\hline
\end{tabular}

Sumber: Data Primer, 2021

\section{PEMBAHASAN}

Kehamilan merupakan suatu proses panjang yang dihadapi oleh seorang wanita dan tidak lepas dari perubahan tidak hanya dalam bentuk fisik tetapi juga mental. Beberapa karakteristik yang melekat pada ibu hamil bisa menjadi salah satu hal yang mempengaruhi tinggi rendahnya respon terkait mental pada ibu hamil. Salah satu nya adalah umur. Umur ibu hamil memiliki kontribusi terhadap risiko kejadian kesehatan mental ibu hamil. Berdasarkan teori, kehamilan pada umur yang terlalu muda dan tua termasuk dalam kriteria kehamilan risiko tinggi. Keduanya berperan dalam peningkatan angka morbiditas dan mortalitas pada ibu maupun janin. Kehamilan di umur muda (kurang dari 20 tahun) berkaitan dengan peningkatan kejadian komplikasi medis dan komplikasi obstetrik karena kondisi fisik belum $100 \%$ siap dalam menjalani kehamilan. Sia 35 tahun keatas pun dianggap menjadi risiko tinggi untuk menjalani kehamilan karena kemungkinan terjadinya kelainan bawaan dan beberapa penyulit di waktu bersalin nantinya. Di kurun waktu ini angka mortalitas ibu dan janin juga tinggi sehingga bisa mengganggu kesehatan mental ibu hamil khususnya untuk respon kecemasan. Umur yang dianggap paling aman menjalani kehamilan dan persalinan adalah 20-35 tahun. Di rentang umur ini kondisi fisik wanita dalam keadaan prima. penelitian ini sejalan dengan penelitian Heriani (2016) tentang hubungan yang signifikan antara umur ibu dengan kecemasan yang dialaminya (Heriani, 2016). Yasin (2019), juga menemukan ada hubungan yang bermakna antara umur ibu dengan tingkat kecemasan dalam menghadapi masa persalinan(Yasin Zakiyah, Sumarni Sri, 2019).

Karakteristik tingkat pendidikan turut memberikan pengaruh terhadap respon kesehatan mental ibu hamil. Orang dengan tingkat pendidikan tamat akademi/perguruan tinggi termasuk orang dengan pendidikan yang tinggi. Menurut teori, tingkat pendidikan seseorang berpengaruh dalam memberikan respon terhadap sesuatu yang datang baik dari dalam maupun dari luar. Orang yang akan mempunyai pendidikan tinggi akan memberikan respon yang lebih rasional dibandingkan mereka yang berpendidikan lebih rendah atau mereka yang tidak berpendidikan. Kecemasan adalah respon yang dapat dipelajari. Dengan demikian pendidikan yang rendah menjadi faktor penunjang terjadinya kecemasan. Penelitian yang dilakukan oleh WHO, menyatakan bahwa pendidikan menengah ke bawah cenderung mendapat kecemasan daripada tingkat pendidikan menengah ke atas. Hal tersebut dikarenakan responden yang pendidikan menengah ke atas berfikiran lebih objektif dan berwawasan luas serta lebih mampu memikirkan penjelasan masalahnya.

Selain itu, tingkat pendidikan yang tinggi akan memperluas pandangan dan ruang lingkup pergaulan, sehingga tingkat pendidikan yang lebih tinggi akan mempermudah seseorang untuk menerima informasi tentang kesehatan sehingga akan 
menurunkan tingkat kecemasan. Dorongan moril maupun materil yang diberikan anggota keluarga untuk mewujudkan suatu rencana merupakan hal yang dapat memberikan keuntungan emosional atau pengaruh pada tingkah laku seseorang. Temuan penelitian ini tidak sejalan dengan teori yang telah dipaparkan sebelumnya, hal ini dikarenakan bahwa dengan status pendidikan yang cukup tinggi untuk perempuan maka pemikirannya akan bercampur dengan keinginanya untuk mengejar dan mengembangkan karir. Selain itu, di masa pandemic Covid 19, kemampuan memahami informasi tentang COVID-19 akan meminimalkan kecemasan pada ibu hamil sehingga akan meningkatkan kemungkinan ibu untuk patuh dalam memeriksakan kehamilannya (Nugraheni et al, 2021). Namun, dalam penelitian ini tidak sejalan dengan pernyataan tersebut. Berdasarkan hasil observasi dan wawancara ibu hamil, mereka bahkan lebih takut dan cemas karena informasi tentang Covid 19 malah membuat mereka semakin takut dengan kesehatannya juga bayi dalam kandungannya. Ketakutan ini juga didukung dengan munculnya kluster penderita Covid 19 pada bidan-bidan yang bekerja di wilayah tersebut. Beberapa responden berpendapat bahwa orang yang berkecimpung di dunia kesehatan dan memiliki pengetahuan memadai tentang pencegahan Covid 19 bisa terinfeksi Covid 19.

Pekerjaan merupakan salah satu karakteristik responden. Umumnya responden dalam penelitian ini memiliki status tidak bekerja atau sebagai ibu rumah tangga. Secara logis, ibu yang tidak bekerja seharusnya tidak mengalami kecemasan karena kegiatannya hanya berfokus sekitar rumah tangga saja. Namun persentase tertinggi penderita kecemasan berada pada kelompok yang tidak bekerja. Setelah mewawancarai beberapa responden, diketahui bahwa kehidupan mengurus rumah tangga memiliki tekanan yang cukup besar. Responden kurang berkomunikasi dan berbagi dengan orang lain sehingga rasa ketidaknyamanan yang dirasakannya hanya dipendam. Apalagi untuk responden yang memiliki balita dengan rentang umur yang tidak terlalu jauh yang sedang mengalami masa aktif dalam bermain.

Menurut Takegata, Ohashi, Lazarus dan Kitamura (2017), sejumlah faktor yang berperan dalam munculnya persoalan psikologis pada masa perinatal diantaranya adalah: faktor biologis (seperti anemia); faktor demografis (misalnya, kemiskinan); hubungan interpersoanal (misalnya, KDRT, kehamilan yang tidak diharapkan); faktor kepribadian yang lemah (seperti, keyakinan diri dan penghargaan diri yang rendah). Selain itu juga terdapat faktor-faktor yang terkait dengan budaya, terutama pada masyarakat Asia, seperti preferensi terhadap jenis kelamin tertentu. Kondisi pandemi covid 19 tidak hanya berdampak pada gangguan kesehatan mental ibu hamil tapi juga berdampak pada kesehatan mental seluruh golongan masyarakat secara umum. Namun, ibu hamil merupakan golongan rentan terhadap segala perubahan yang terjadi di dalam tubuhnya baik itu perubahan fisik maupun mentalnya.

Kecemasan merupakan salah satu bentuk gangguan kesehatan mental yang paling banyak ditemukan dalam penelitian ini dibandingkan bentuk gangguan metal lainnya yakni depresi dan stress. Hal ini dikarenakan masa kehamilan merupakan kondisi rentan terjadi perubahan emosi Kecemasan merupakan respon individu terhadap suatu keadaan yang tidak menyenangkan dan dialami oleh semua makhluk hidup dalam kehidupan sehari-hari dan pada saat pengambilan data sedang terjadi pandemic covid 19 yang menjadi salah satu pemicu ketakutan dan kegelisahan ibu hamil yang harus sering kali memeriksakan kehamilannya di pusat pelayanan kesehatan yang dalam anggapan mereka merupakan salah satu tempat dengan risiko tinggi penularan covid 19. Hasil penelitian ini sejalan dengan temuan Suparman, Sapruddin dan Mamlukah (2020) di Puskesmas Sindangwangi, Kabupaten Majalengka yang menunjukkan responden yang memiliki kecemasan normal sebanyak $10 \%$, kategori ringan sebanyak 38,3 \%, kategori sedang 48,4 $\%$ dan kategori berat sebanyak 3,3 \%. 
Gangguan kesehatan mental depresi juga ditemukan di penelitian ini meskipun jumlahnya tidak sebanyak gangguan kecemasan. Namun, angka kejadiannya tetap berada dalam kondisi mengkhawatirkan. Pada situasi sebelum terjadi pandemic Covid 19, frekuensi kejadian depresi secara global sekitar $10 \%$ terjadi pada ibu hamil bahkan di beberapa Negara berkembang lebih tinggi yakni 16\% (Zhang et al., 2020). Palagi pada situasi pandemic Covid 19, ketika ibu hamil kemungkinan akan sulit mengakses pelayanan kesehatan khususnya konseling terhadap kesehatan mental dan beberapa ketakutan dan kondisi yang dirasakan selama hamil. Di China, sebanyak 5,3\% ibu hamil mengalami gejala depresi, 6,8\% mengalami kecemasan, $\quad 2,4 \% \quad$ mengalami ketidaknyamanan fisik, 2,6\% mengalami insomnia, dan $0,9 \%$ mengalami Post- Traumatic Stress Disorder (PTSD)(Zhou et al., 2020).

Kejadian postpartum blues dan depresipada ibu hamil sudah ada sebelum pandemic Covid 19 sehingga ibu hamil untuk harus berkunjung ke fasilitas kesehatan, dan berkonsultasi dengan tenaga kesehatan untuk mendapatkan pelayanan prenatal dan antenatal. Pandemi Covid 19 menempatkan posisi ibu hamil sebagai pihak yang rentan. Kerentanan itu berasal dari kekhawatiran ibu hamil terhadap potensi penularan virus Covid 19 pada saat ke pusat pelayanan kesehatan melalui tenaga kesehatan kesehatan mental dan kurangnya interaksi dengan keluarga dan dukungan sosial selama kehamilan, persalinan, dan masa nifas dalam pandemi saat ini.Berbagai pembatasan aktifitas social diterapkan pada masa pandemic Covid 19 (Bender et al., 2020).

Peningkatan stres juga terjadi selama masa pandemi penyakit menular Covid 19 (Saccone et al., 2020). Enam dari delapan wanita $(75 \%)$ yang dites positif melaporkan pengalaman negatif di rumah sakit akibat kurangnya dukungan penyedia dan pasangan dan pemisahan neonatal setelah lahir. Di antara 310 wanita, sebanyak 34,4\% wanita multipara melaporkan peningkatan kecemasan pascamelahirkan dibandingkan dengan persalinan sebelumnya karena kekhawatiran tentang paparan infeksi di rumah sakit dan kurangnya dukungan sosial (Bender et al., 2020)

\section{KESIMPULAN}

Gangguan kesehatan mental pada ibu hamil yang ditemukan dalam penelitian ini digolongkan menjadi 3 yaitu gangguan depresi, kecemasan dan gangguan stress. Adapun frekuensi kejadiannya yakni sebanyak 35 ibu hamil mengalami depresi $(29,9 \%)$, yang mengalami kecemasan sebesar 52 orang $(44,4 \%)$, dan yang mengalami stress sebanyak 21 orang $(17,1 \%)$. Dari angka tersebut bisa diketahui bahwa kesehatan mental pada ibu hamil merupakan suatu isu yang harus mendapat perhatian khusus apalagi dengan kondisi pandemic covid 19 yang menjadi salah satu faktor meningkatnya gangguan kesehatan mental. Adapun keterbatasan penelitian ini adalah

Diharapkan tenaga kesehatan khususnya bidan tidak hanya memperhatikan masalah kesehatan fisik ibu dan janin, tapi juga masalah kesehatan mental ibu hamil sehingga Kecemasan selama kehamilan bisa segera diidentifikasi dan mendapatkan perhatian khusus dalam rangka pencegahan ke tahap yang lebih parah. Selain itu, Penelitian selanjutnya diharapkan dapat mengidentifikasi faktor-faktor lain yang mempengaruhi Kecemasan pada ibu hamil yang tidak termasuk dalam penelitian ini.

\section{DAFTAR PUSTAKA}

Abazarnejad T, Ahmadi A, Nouhi E, et al. (2019). Effectiveness of psychoeducational counseling on anxiety in preeclampsia. Trends Psychiatry Psychother, 41, 276-282.

Afritayeni, A., Yanti, P. D., \& Angrainy, R. (2018). Analisis Perilaku Seksual Berisiko Pada Remaja Terinfeksi Hiv Dan Aids. Jurnal Endurance, 3(1), 69. https://doi.org/10.22216/jen.v3i1.2717

Bender, W. R., Srinivas, S., Coutifaris, P., Acker, A., \& Hirshberg, A. (2020). The Psychological Experience of Obstetric Patients and Health Care Workers after 
Implementation of Universal SARS-CoV-2

Testing. American Journal of

Perinatology, 37(12), 1271-1279. https://doi.org/10.1055/s-0040-

1715505

Heriani. (2016). Kecemasan dalam Menjelang Persalinan Ditinjau Dari Paritas, Usia dan Tingkat Pendidikan. Jurnal IImu Kesehatan Aisyah, 1(2).

Liang, H., \& Acharya, G. (2020). Novel corona virus disease (COVID-19) in pregnancy: What clinical recommendations to follow? Acta Obstetricia et Gynecologica Scandinavica.

Nath S, Ryan EG, Trevillion K, et al. (2018). Prevalence and identification of anxiety disorders in pregnancy: the diagnostic accuracy of the two-item Generalised Anxiety Disorder scale (GAD-2). BMJ Open, 8.

Rezaee, R., \& Framarzi, M. (2014). Predictors of mental health during pregnancy. Iranian Journal of Nursing and Midwifery Research, $19(7$ Suppl 1), S45-50. http://www.ncbi.nlm.nih.gov/pubmed/ 25949251\%0Ahttp://www.pubmedcent ral.nih.gov/articlerender.fcgi?artid=PMC 4402987

Saccone, G., Florio, A., Aiello, F., Venturella, R., De Angelis, M. C., Locci, M., Bifulco, G., Zullo, F., \& Di Spiezio Sardo, A. (2020). Psychological impact of coronavirus disease 2019 in pregnant women. American Journal of Obstetrics and Gynecology, 223(2), 293-295. https://doi.org/10.1016/j.ajog.2020.05. 003

Sasaki T-K, Yoshida A, K. K. (2013). Attitudes about the 2009 H1N1 influenza pandemic among pregnant Japanese women and the use of the Japanese municipality as a source of information. .. Southeast Asian J Trop Med Public Health, 388-399.

WHO. (2020). Maternal mental health. https://www.who.int/teams/mentalhealth-and-substance-use/maternalmental-health

Yasin Zakiyah, Sumarni Sri, M. N. D. (2019). Hubungan Usia Ibu dan Usia Kehamilan dengan Kecemasan Ibu Hamil dalam
Menghadapi Persalonan Di Polindes Masaran Kecamran Bluto. Prosiding 1st Seminar Nasional "Arah Kebijakan Dan Optimalisasi Tenaga Kesehatan Menghadapi Revolusi Industri 4.0," 162168.

Zhang, H., Tang, L., Ye, Z., Zou, P., Shao, J., Wu, M., Zhang, Q., Qiao, G., \& Mu, S. (2020). The role of social support and emotional exhaustion in the association between work-family conflict and anxiety symptoms among female medical staff: $A$ moderated mediation model. BMC Psychiatry, 20(1), 1-9. https://doi.org/10.1186/s12888-02002673-2

Zhou, Y., Shi, H., Liu, Z., Peng, S., Wang, R., Qi, L., Li, Z., Yang, J., Ren, Y., Song, X., Zeng, L., Qian, W., \& Zhang, X. (2020). The prevalence of psychiatric symptoms of pregnant and non-pregnant women during the COVID-19 epidemic. Translational Psychiatry, 10(1). https://doi.org/10.1038/s41398-02001006-x 